\title{
ORCHIDS AT WRITHLINGTON SCHOOL, ORCHID CONSERVATION IN THE COMMUNITY
}

\author{
Simon Pugh-Jones \\ Writhlington School, Radstock, Bath, BA3 3UD, England. spughjones@tiscali.co.uk
}

This lecture will outline my work with orchids at Writhlington School and the range of outcomes that make this the special project it has become. I will then focus on current ex-situ conservation projects and identify lessons for community based orchid conservation. Expect a rapid journey through science, conservation and young peoples achievement.

Our starting point is the School and its greenhouse. Writhlington is a Comprehensive School (pupils 11 to 18 years old) serving the old coal mining town of Radstock and the surrounding villages dominated by the industries of quarrying and printing.

The School greenhouse is an ageing structure $12 \mathrm{~m}$ by $8 \mathrm{~m}$ divided into about three sections that run at intermediate, cool and even cooler and the plants are grouped roughly in genera for the convenience of the pupils. This allows us to grow a wide range of tropical orchids. Each pupil in 'Greenhouse club' is responsible for the care of a different genus and thus becomes an expert in their field quite quickly. Giving the pupils real responsibility has been the key to our success as the pupils become passionate about orchids.

As well as the greenhouse we have two other key facilities, the School orchid laboratory and the Rugby Field.

We built our Orchid propagation lab in a room that used to be a girls toilet. Instead of the cubicles and basins we now have two lamina flow cabinets and rows of shelves and grow lights. It's a magical spot and pupils spend hours looking through the jars to spot germination. We have been really pleased to find that growing Orchids from seed is not difficult if you have suitable equipment. Twelve year olds have no problem in achieving high success rates. At this point I must thank those at Kew and Greenaway Orchids that have given us help and advice.
Our rugby field is a special place since the first flowering of Ophrys apifera (Bee Orchid) six years ago. Five years earlier I had arranged for changed management of the field so that it is not cut for rugby after Christmas and a local farmer takes a late Hay cut in August. The field is now a wonderfully bio-rich meadow with and rapidly growing Bee Orchid Population and an emerging Pyramidal Orchid population. This practical example of in-situ conservation offers excellent research opportunities to our pupils as well as a starting point for our ex-situ conservation work.

Making the most of these facilities at the School opens a wide range of opportunities to the School pupils and the local community. The opportunities can be split into:

- Science opportunities

- Conservation opportunities

- Enterprise opportunities

- Opportunities for personal development.

The four are intertwined but I would like to give some real examples of how they work in a school and impact on orchid conservation.

Through our orchid work we have linked with some key partners including the micropropagation department at Kew, The Royal Horticultural Society, Bristol Zoo, The Eden Project and The Rio Atlantic Forest Trust. These partners allow students to develop knowledge and skills and take part in significant research. In each of the past three years Writhlington Students have reached the British finals of 'Young Scientist of the Year'. Through research and work experience the Students also develop higher education and career plans.

Pupils have developed innovative enterprise projects utilizing their specialist orchid knowledge and 
skills, developing real commercial products. They sell to the public, including high profile customers like Cherie Blair (the Prime Ministers Wife), and sell Business to Business. This work has helped us to develop the concept of conservation enterprise - conservation that is self funding.

This brings me to conservation. As I have said pupils are involved in in-situ and ex-situ conservation. Ex-situ conservation has two elements. Ex-situ conservation of orchid species local to the School and ex-situ conservation of tropical species linked to partner organisations.

Writhlington School is situated on limestone hills in the West of England and expeditions with pupils have identified sites of more than 20 of Britain's 50 native Orchid species within 15 miles of the School. Searching for and finding these sites formed the basis of 'The Radstock Native Orchid Project', where school pupils and an adult community group are working to raise these species from seed. The community group includes local farmers, gardeners, housewives, a technician and a retired electrician. A mixed group with a variety of skills and goals, but a group that now shares a passion for conservation and a range of high level skills.

Our local orchids are not endangered but are locally rare and many populations are vulnerable. We accept that the greatest threats to biodiversity are not in Western England but in the tropical World and in response we have turned our attention to ex-situ conservation of tropical species. In this field we feel have three key strengths:

- The skills and facilities at the School.

- Our well developed community involvement.

- Our enterprise experience and connections.

To give a clear outline of how this works in practice I will describe our newly launched project 'The Sikkim ex-situ Cymbidium conservation project'.

The project is based around three Project partners:

- Sikkim - Mohan Predhan -Member and Secretary, Indian Sub-continent Regional Orchid Specialist Group. Plus Sikkim Schools.

- Writhlington School - Simon Pugh-Jones, Teacher, and community conservation group of pupils and adults.
- Eden Project.- initial contact Don Murray, Curator Humid Tropics.

The need for the project has been identified by Mohan Predhan. He has identified local Cymbidium species as under great pressure from collection for sale to people in towns and cities who use plants in their gardens. He is also concerned that conservation is not a priority for the majority of the population.

The Project plan identifies clear roles for each of the partners to deliver results in Sikkim.

Mohan Pradhan will send seed of key species to Writhlington School for germination. Writhlington School and its community conservation group will raise large numbers in flask and flasks will be sent with financial support to selected village schools in Sikkim. The School students in Sikkim will then grow the seedlings into plants for distribution in community at low cost. A proportion of seedlings will be retained by Writhlington School to raise the money to send to Sikkim and cover costs of production. To generate this funding seedlings will be sent to the Eden Project for suitable packaging as conservation product and sold through Eden Shop (which has two million visitors a year). In this way the project will be self funding and not reliant on sponsorship or grant aid.

The Project will have a number of outcomes, both in Sikkim and England:

- Artificially raised plants will become available in large quantities in Sikkim reducing pressure for collection of wild plants. School pupils and communities in Sikkim will become actively involved in conservation and the schools involved will benefit from the funding provided by the project. It is hoped that the community focus of project will avoid commercial conflicts.

- Writhlington School students benefit from links with Sikkim schools, and the opportunity to develop their science and enterprise skills.

- The Eden Project gains involvement in a practical, manageable and self funding conservation project and the customers who buy the seedlings from the Eden Project will gain involvement in conservation and a desirable product.

Clearly there is a need for Project guarantees and I 
consider the best approach is to work through the auspices of the Orchid Specialist Group of IUCN, and ensure that financial arrangements are set up to ensure that surplus generated is sent to Sikkim.

The longer term aims are for the Project to act as a model for the future, and for the work in Sikkim to be self sustaining and independent once funding has set up full facilities for raising the orchids within local school. Writhlington will then move to a similar project in another area.

I believe that our projects at Writhlington demonstrate that Schools have the potential to play a key role in conservation. Schools can be a major resource as they are an effective link to community involvement in projects and contain the key raw material for change, the energy and commitment of young people.

Simon Pugh-Jones has won National acclaim for pioneering work with Orchids in Education. As a science teacher at Writhlington Comprehensive School he has introduced orchid growing to a generation of young people and developed a wide range of ground breaking conservation projects. The value of his work has been recognized through the award of 'Teacher of the Year' for the West of England and National TV coverage. Simon began growing orchids at the age of thirteen and worked under the guidance of Keith Andrew at Plush while at School and College. Becoming head of physics at Writhlington School in 1988, he has transformed the Schools extensive horticultural area into a vibrant orchid collection supported by a productive orchid propagation laboratory and extensive scientific research. 